\title{
Recommendation and Repurchase Intention for Health Service Based on Medical Tourism
}

\section{Ririn Tri Ratnasari, Sedianingsih, Ari Prasetyo, and Hendarjatno}

Faculty of Economics and Business, Universitas Airlangga

\section{Abstract}

The recent trend of many people moving to developing countries to do medical treatment because of the cost factors offered by various developing countries of quality care at affordable prices, although traditional patterns still continue. This raises opportunities for patients to use the best world-class health services offered professionally and experienced, at the most advanced medical facilities in the field of technology, and at affordable costs (Thilakavathy, 2015). Therefore, this study aims to determine the determination of the intention to recommend and intention to reuse medical tourism-based health services.The research method used is quantitative surveys and deepens the results by using in depth interviews. The sampling technique

Corresponding Author: Ririn Tri Ratnasari

ririnsari@feb.unair.ac.id

Received: 10 February 2019

Accepted: 14 March 2019

Published: 28 March 2019

Publishing services provided by Knowledge E

(c) Ririn Tri Ratnasari et al. This article is distributed under the terms of the Creative Commons Attribution License, which permits unrestricted use and redistribution provided that the original author and source are credited.

Selection and Peer-review under the responsibility of the ICIEBP Conference Committee. in this study was non probability sampling, with a purposive sampling technique. The number of samples in the pre survey and main survey research totaled 440 people. The second stage, conducted a pre survey, namely the distribution of questionnaires to 40 respondents. Then, the third stage was carried out by continuing with a closed-ended structure for 400 respondents consisting of 100 outpatients in hospitals in Surabaya, 100 consumers in Surabaya, and 200 consumers outside Surabaya Indonesia. The results of this study indicate that the quality of medical services to have an effect on the intention to recommend health services and the intention to repurchase of health services, and patients and medical equipment technology did not have influence on the intention to recommend health services. But patients and medical equipment technology did not have influence on the intention to repurchase of health services.

Keywords: Recommendation Intention, Repurchase Intention, Health Service Medical Tourism

\section{Introduction}

The medical tourism industry is currently regarded as one of the fastest growing industries in this competitive environment that continues to be faced with new problems, obstacles, disputes and threats. Movement of patients including trips to other countries to get medical treatment. Traditionally, people from underdeveloped and developing countries will go to developed countries to carry out medical treatment and surgical 
procedures because of the unavailability of treatment in their host country (Hopkins et al., 2010). But now the trend has changed. The recent trend of people moving from developed countries to developing countries to do medical treatment because of the cost factors offered by various developing countries is quality care at affordable prices, although traditional patterns still continue. Another reason to travel is that some medical procedures are illegal in the country. This involves visitors traveling to a particular destination utilizing patient opportunities for the best world-class health services offered with professionals and experienced, at the most advanced medical facilities in the field of technology, and at affordable costs "(Thilakavathy, 2015).

The hospital as one of the health facilities that provide health services to the community has a very strategic role in accelerating the improvement of public health status. Therefore, hospitals are required to provide quality services in accordance with established standards and can reach all levels of society. According to Azwar (1996), quality health services are health services that can satisfy every service user in accordance with the level of satisfaction of the average population and its implementation in accordance with the standards and professional codes of ethics that have been set. The old paradigm has shifted into a new paradigm marked by the management of an organization that applies a quality management pattern and reliable service in the face of global competition and work dynamics, including the health sector.

Surabaya has claimed to be the City of Services and Trade. More than that, the city of Surabaya is a city of business with various activities that take place (http://surabaya. go.id/berita/8177-sosial-ekonomi). Business carried out in the field of tourism services is very promising. Tourism services are not only about natural beauty, culinary and shopping, but also health. One of the Government's programs in the field of health is that health services with complete infrastructure are carried out evenly throughout the city of Surabaya, including hospitals.

The function of the Hospital is as a place for organizing medical services, medical support, administration and management can also be used as a place of education / training and development. At present, hospitals in Surabaya continue to improve by completing various modern medical facilities and experts who have received various awards from the international medical world. It is expected that the various facilities obtained are more modern and comfortable. Ranging from complete specialist services, inpatient facilities to medical support services using the latest technology.

A full range of medical services are also available, including emergency services, laboratories, inpatient facilities, and specialization clinics such as aesthetic service centers, and cancer service centers. There are also child health clinics, counseling, teeth, 
eyes, fertility, surgery, heart disease, internal medicine, orthopedics, obstetric obstetric services, and physiotherapy. There are even private hospitals that provide inpatient rooms specifically designed with star-rated hotel standards that are comfortable to help the healing process of patients. Medical support services that are technologically sophisticated and complete will support accurate and accurate diagnoses (http://www. surabaya.go.id/berita/8241-kesehatan).

\section{Theory}

\subsection{Medical tourism}

Medical tourism is the act of seeking medical services in a foreign country: it is the process by which tourists visit medical places for the purpose of healing and relaxation (Hunter, 2007). Humans have traveled abroad to access treatment for years (Richard, Melisa, \& Rupa, 2011). However, the journey developed to developing countries to access medical services at lower costs is a new trend (Johnson, Youngquist, Garman, Hohmann, \& Cieslak, 2015; Misung, Heesup, \& Tim, 2012). The reasons for medical trips to international dormitories vary by country or region. For example, because the cost of health services is very high, citizens of developed countries seek medical treatment abroad, especially in developing countries (Wongrukmit and Thawesaengskulthai, 2014).

Awadzi and Panda (2005) note that medical tourists are influenced by factors of encouragement and attraction. The push factor is intrinsic power in humans, for example the desire for personal privacy, an increase in personal beliefs and appearance, while the pull factor is extrinsic style related to goals, such as reputation, known technological status in health care facilities, advertising, prices, doctor's experience and WOM ((Ye, Yuen, Qiu, \& Zhang, 2008)). Kigsbury, Snyder and Jonston (2010), examine motivation and encouragement factors for patients deciding to leave their country and seek medical care abroad. Patients are attracted to hospitals that are known for their quality of care and hospitals where staff speak their native language (Crooks et al., 2010).

\subsection{Health services}

Measuring and assessing the quality of health care services offers opportunities for managers in this sector to develop mechanisms / operating systems, procedures and protocols that enhance their programs. The benefits are clear in both the public and 
private sectors. With effective public management, the government can achieve greater social returns on investment in public resources. In the private sector, managers can make healthcare services very competitive and cost effective. To evaluate the quality of services in health care efficiently, deeper understanding of the nature of doctor-patient relationships is very important to identify and measure service attributes. Naidu (2008), based on the results of the study, outlined a comprehensive model of the factors that influence satisfaction and quality of health services. He identified the following as key dimensions: access, cost, patient care, doctor's role and behavior, and tangible factors, such as appearance and structure of the facility. In addition, user perceptions appear to be mediated by sociodemographic related factors (Alrubaiee and Alkaa'ida, 2011; Naidu, 2008; Narang, 2011).

In the context of the quality of health care services, Zineldin (2006) argues that the quality of care and service is very important because of the nature of seriousness and possible negative consequences that may arise due to compromise on the essential dimensions of service quality. Measuring the quality of health care also helps medical professionals understand and compare different health care programs (Andaleeb, 2001), understand the priorities of patients in various health care treatments and to relate them to patient satisfaction ( Jackson et al., 2001). However, the problem identified by many experts is the quality of health care services is a very complex and multi-dimensional construction, therefore it poses challenges for researchers in terms of measurement (Silvestro, 2005).

Fundamentally, there is a difference between the quality of care delivered to patients known as the quality of care observed and the patient's perception of the quality of care (Palmer and Simmons, 1995). The quality of care observed is identified as whether health care services adhere to the standards set for specific diseases and their resolutions. On the other hand, the perceived quality of care is related to how patients perceive care and treatment (Donabedian, 1988; Ross et al., 1993). It has been found that patients measure the level of quality of medical care based on various dimensions of service delivery such as empathy of service providers, health care facilities and empathy of support staff (Ettinger, 1998).

\subsection{Recommendation intention}

There are several definitions of intention to recommend (word of mouth) according to the exposure of several experts. Rosen (2014) defines the intention to recommend as all word of mouth communication about a brand. Tjiptono (2010) defines the intention to 
recommend as a statement (personally or non-personally) that is conveyed by someone other than the organization to the customer. Based on the two definitions of intention to recommend it can be concluded that the intention to recommend is the amount of word of mouth communication about a particular product, service, or company at each stage at a certain time. The intention to recommend this is usually more quickly accepted by customers because those who convey it are those they can trust. In addition, the intention to recommend is also quickly accepted as a reference because service customers are usually difficult to evaluate services that they have never bought or have not yet felt themselves.

Intention to recommend is often referred to as free advertising (free advertising) so that many parties consider that the intention to recommend is advertising. Swan and Oliver (1989) as quoted by Rosen (2014) state that the intention to recommend and advertising are two different things. Advertising can be interpreted as various forms of non-personal presentation of ideas, products or services financed by the sponsor (company), while the intention to recommend is more emphasized on personal relationships between customers and other customers based on experience with a product that is communicated to other customers. Sometimes the intention to recommend is done by giving rewards to people who do it or done through electronic media, sometimes also the intention to recommend being done voluntarily by consumers because they are satisfied or because they are not satisfied with the performance of the product or service. To make it easier to distinguish between advertising and intention to recommend, then the intention to recommend can be identified based on the characteristics it has.

\subsection{Intention to repurchase/revisit health services}

There is a positive relationship between customer satisfaction, post-purchase behavior and business performance. Customers who feel satisfied in their purchases will have a positive effect on post-purchase behavior, meaning that consumers who feel fulfilled the level of expectation before the purchase with the perceived performance after purchase will increase purchase commitment such as repurchase intention, percentage of purchase amount, number of brands purchased, and some of them. Repurchase intention is defined as a strong desire to repurchase (Jasfar, 2002). Miller et al., (2000) as quoted by Qader (2008) defines the intention to repurchase as a person's mental state which reflects the plan to take several actions within a certain period of time. Keller 
(2010) states that the intention to repurchase is how much the consumer might buy a brand or how likely the consumer is to move from one brand to another.

Howard (1989) as followed by Sutantio (2004), intention to repurchase is defined as statements relating to the mind that reflect the plan of the buyer to buy a particular brand in a certain period. In essence, buying intention is a possibility for someone interested in buying another product in the future. This definition is assumed to be the direct antecedent of behavior. The application in research to the definition of purchase intention is that the customer will take action to repurchase in the future as a direct response to post-purchase behavior within a certain period of time. Assael (2010) defines purchase intention as the customer's desire to make repeat purchases in the future. Research conducted by Cronin and Taylor (2012) states that repurchase intention positively supports the relationship between image and satisfaction with repurchase intention behavior. The intention to repurchase in conjunction with visage visits in purchasing tourism services is referred to as the behaviora itention to visit.

In the service quality model of Grönroos (1984), the quality of service delivery processes and achievement of results is considered important. The emphasis of the research that applies to the process of outcomes has been questioned (Maddern et al., 2007; Ladhari, 2008). For example, Brady and Cronin (2001) identify service outcomes, along with interaction and environment as three key dimensions of service quality. Customers will logically be interested in repurchasing services if they get what they expect. Some empirical studies show that service quality greatly influences behavioral intentions (Parasuraman et al. 1988 and 1991; Boulding et al. 1993). Taylor and Baker (1994) show the relationship between service quality and customer satisfaction. However, the way consumers combine quality services into satisfaction is difficult to separate. Researchers describe satisfaction as a broader concept while service quality is as specific as service dimensions (Parasuraman et al., 1994). Aditi Naidu (2009) various factors contribute differently to patient satisfaction and service quality. When evaluating customer service quality is high, customer behavior intentions are favorable, which in turn strengthens individual loyalty with the company. In particular, Woodside et al. (1989) found a significant correlation between overall patient satisfaction and repetitive behavioral intention to select hospitals.

Technological advances in the health sector can affect a person in utilizing health services. Technological advances can reduce morbidity or the need for treatment. such as the discovery of vaccines to prevent disease. On the other hand, technological advances can also increase the use of health services, such as heart, kidney transplants, 
and progress in the field of radiology can increase the use of health services in the community.

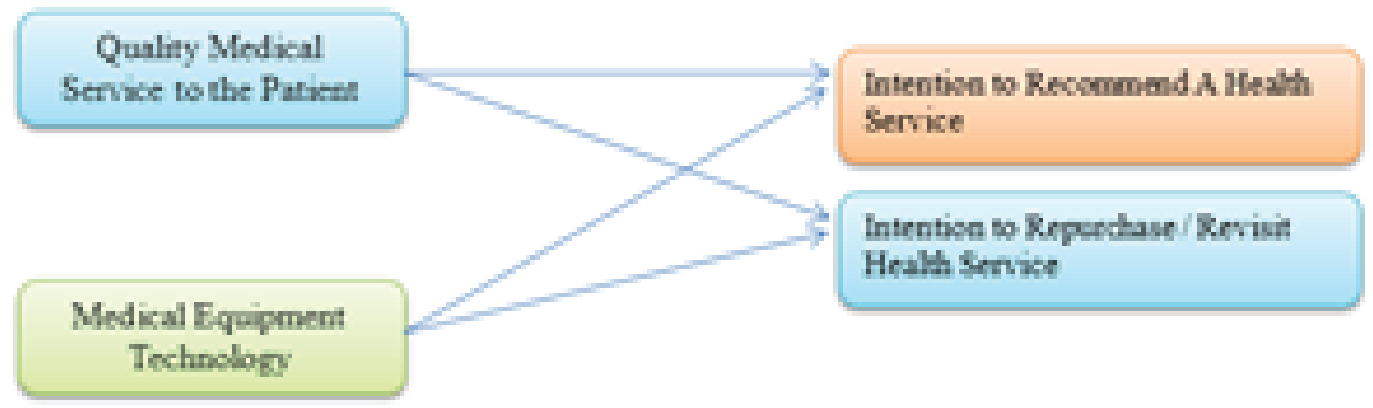

Figure 1: Analysis Model.

\section{Method}

The research method used is quantitative surveys and deepens the results by using in depth interviews. The sampling technique in this study was non probability sampling, with a purposive sampling technique. The number of samples in the pre survey and main survey research totaled 440 people. The second stage, conducted a pre survey, namely the distribution of questionnaires to 40 respondents. Then, the third stage was carried out by continuing with a closed-ended structure for 400 respondents consisting of 100 outpatients in hospitals in Surabaya, 100 consumers in Surabaya, and 200 consumers outside Surabaya Indonesia.

\section{Results}

\subsection{Hypothesis testing with partial least square (PLS)}

The PLS test is an analytical method that is not based on many assumptions. Data does not have to be normally distributed, with nominal, ordinal, interval to ratio categories. PLS can be used to confirm the theory and explain whether or not there is a relationship between latent variables. In processing Partial Least Square (PLS) using smartPLS 3, it is carried out in two stages. The first step is to test the outer model. In this stage is to test the validity and reliability. The second step is to test the inner model. In this stage it aims to find out whether there is influence between variables. Tests are carried out using the $t$ test. 


\subsection{Outer model testing stage}

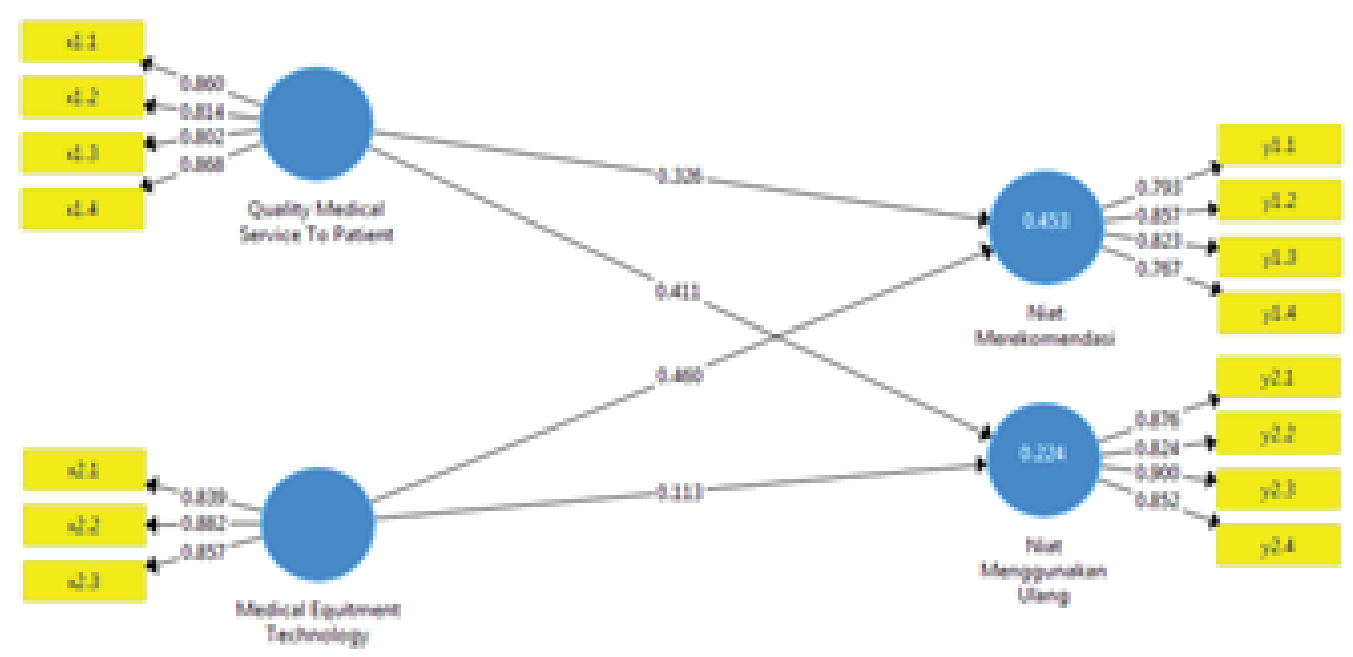

Figure 2: The result of the outer model with the value of outer loading.

The previous page shows the image of the PLS test at the outer model stage on the variable. Tests are performed on all of each variable. The indicator criteria of the variable are said to be valid and reliable concretely if they have a loading factor value greater than or equal to 0.5 and the $t$ test value is $>1.96$.

\subsection{Convergent validity}

The test results of the outer model in the first stage is the value of convergent validity. The results of convergent validity can be seen from the value of the loading factor and the value of $t$ count. The loading factor value is said to be valid, it must be more than 0.5 . While the results of $t$ count can be said to be valid if it is worth more than 1.96. The following are the results of thecomplete convergent validity test:

The calculation results show for the Quality Medical Service (X1), Med Equipement Tech ( $\mathrm{X} 2)$, Intention to recommend (Y1), and the intention to reuse (Y2) shows all items have a factor loading value of more than 0.5 . With this result, all items are valid variables.

\subsection{Extract validity}

The next measurement model is the value of Avarage Variance Extracted (AVE), ie the value indicates the magnitude of the indicator variant contained by the latent variable. Convergent AVE values greater than 0.5 also indicate the adequacy of good validity for 
TABLE 1: Test Results for Convergent Validity in Research Variables.

\begin{tabular}{|c|c|c|c|}
\hline & $\begin{array}{l}\text { Lodat: } \\
\text { Futs }\end{array}$ & $\begin{array}{l}\text { T Statist } \\
\text { co STDEYh }\end{array}$ & Reternge \\
\hline Il 1 \& Quality Madual Senve To Pathett & asb & 30.102 & Wild \\
\hline xl $2<$ Quality Madical_Service To Patient: & 0814 & 33.728 & Vild \\
\hline I1 3<- Qulity Madial Servise To Ratient & 0.02 & 33.31 & Vilid \\
\hline x1_<-Quality Modkal_Senwe To Pated & 085 & 51026 & Vahs \\
\hline 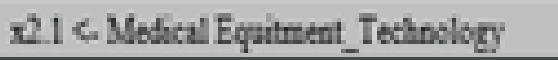 & $\Delta B$ & atsis & Waht \\
\hline$\pi 2<$ Medical Equitent Techology & $\Delta 82$ & 4876 & Vilid \\
\hline 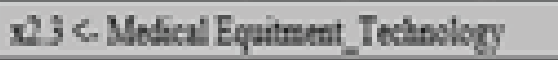 & $\Delta B 1$ & 3777 & Vili \\
\hline 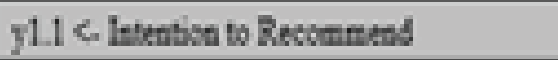 & 0.35 & $53 \pm 59$ & Yald \\
\hline 712 C letenboa to Recummend & 687 & 44.56 & Vild \\
\hline 713<- letmice to Rrument & ons & $\$ 191$ & Valid \\
\hline 1.4<- fetentiat to Recommend & 0167 & 2035 & Vill \\
\hline 2.1 < letenbs is Reparthas & 085 & 37.42 & Wha \\
\hline y22< Itention to Repurchese & ont & 31998 & Valid \\
\hline y $3<$ - Etrtiba to Rerpucher & 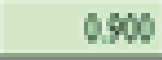 & $\$ 1407$ & Valid \\
\hline 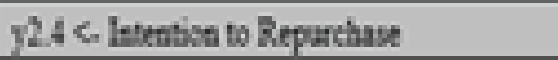 & 0.52 & 4860 & Vils \\
\hline
\end{tabular}

latent variables. The reflective indicator variable can be seen from the value of Avarage variance extracted (AVE) for each construct (variable). A good model is required if the AVE value of each construct is greater than 0.5 .

TABLE 2: Test Results for Extract Validity in All Variables.

\begin{tabular}{|l|r|r|}
\hline & $\begin{array}{l}\text { Average } \\
\text { Variance } \\
\text { Extracted } \\
\text { (AvE) }\end{array}$ & Keterangan \\
\hline Medienal Equituent_Technology & 0.739 & Valid \\
\hline Intretion to Repurchane & 0.746 & Valid \\
\hline Intention to Recommend & 0.657 & Valid \\
\hline Quality Medical Service To Patient & 0.700 & Valid \\
\hline
\end{tabular}

The calculation results show that all constructs of the research variables show that all variables have AVE values of more than 0.5. With this result, all latent variables have sufficient validity. 


\subsection{Reliability}

Construct reliability measured by composite reliability value, the construct is reliable if the composite reliability value is above 0.70 , the indicator is called consistent in measuring its latent variables. The following are the full results:

TABLE 3: Extract Reliability Test Results.

\begin{tabular}{|l|r|r|r|}
\hline & \multicolumn{1}{|l|}{$\begin{array}{l}\text { Crobbachs } \\
\text { Alpha }\end{array}$} & $\begin{array}{l}\text { Composite } \\
\text { Reliability }\end{array}$ & Keteragan \\
\hline Medical Equitment_Techrolsgy & 0.824 & 0.895 & Reliabel \\
\hline Intentica to Repurchane & 0.886 & 0.921 & Relinbel \\
\hline Intention to Recommend & 0.826 & 0.884 & Reliabel \\
\hline Quality Medical Serviee To Patient & 0.857 & 0.903 & Reliabel \\
\hline
\end{tabular}

The test results show that the construct (variable) of all variables has a composite reliability value greater than 0.7 . So it's reliable.

\subsection{Stage structural model}

The structural phase of this model aims to determine whether there is influence between variables. Tests are carried out using the t test. Variables are said to have an influence if the $p$ value is smaller than 0.05 . Likewise, if the relationship between negative variables, the decision is if - $\mathrm{t}$ count is smaller than - $\mathrm{t}$ table.

Calculation results can be seen in the picture on the next page.

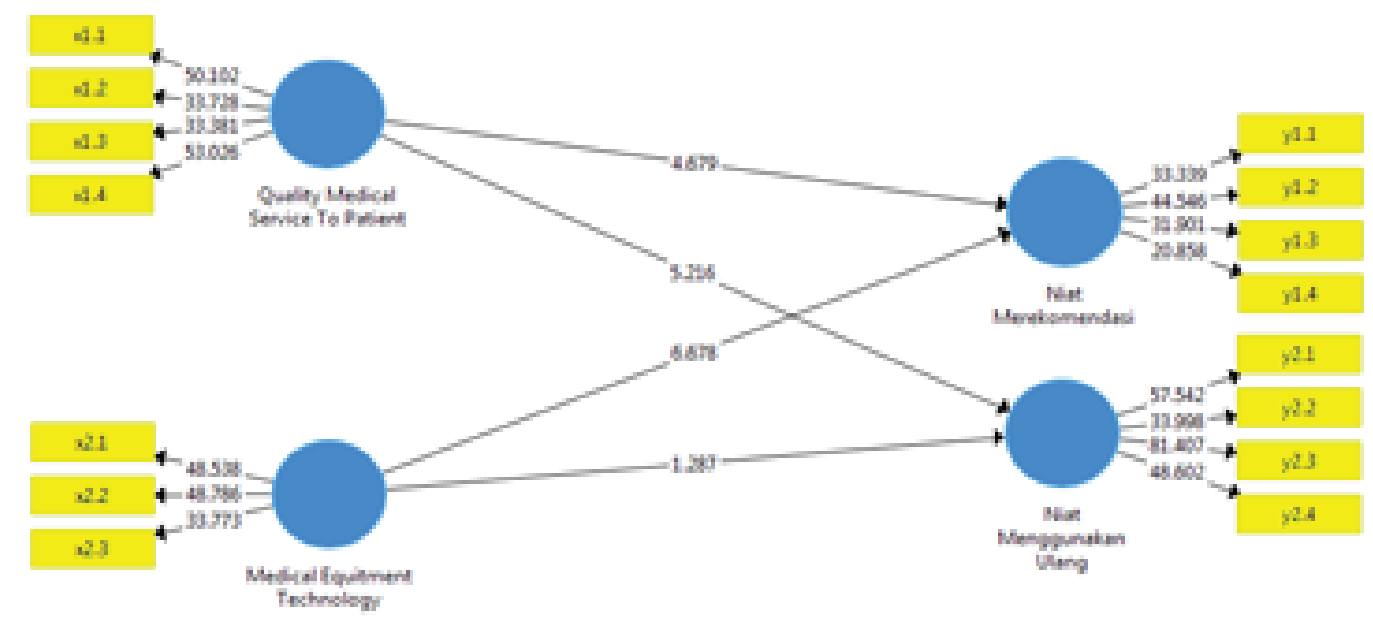

Figure 3: Structural Model Test. 


\subsection{Hypothesis testing}

The following is the estimate value of each relationship between the research variables:

TABLE 4: Inter Variable Coefficient Estimate Value.

\begin{tabular}{|c|c|c|c|c|c|}
\hline & $\begin{array}{l}\text { Orifull } \\
\text { Surple } \\
\text { (0) }\end{array}$ & $\begin{array}{l}\text { Sreple } \\
\text { Mexin } \\
\text { (M) }\end{array}$ & $\begin{array}{l}\text { Sundred } \\
\text { Druixion } \\
\text { (STDEV) }\end{array}$ & $\begin{array}{l}\text { T Stuhises } \\
\text { COSTDEVD }\end{array}$ & $\stackrel{P}{\text { Vubas }}$ \\
\hline 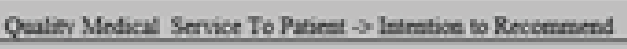 & 0.328 & 0.332 & 0.070 & 4.679 & 0.000 \\
\hline 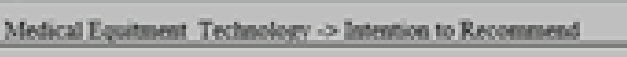 & $0+60$ & 0457 & 0009 & 6878 & 0000 \\
\hline 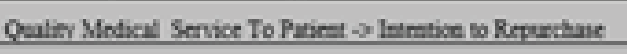 & 0.411 & 0.407 & 0.079 & 5.216 & 0.000 \\
\hline Medical Esutment Techaskosy $>$ Intension to Repurchave & 0113 & 0.117 & $0 \cos$ & 1.287 & 0.196 \\
\hline
\end{tabular}

Based on the Table above, it can be interpreted as follows:

1. The magnitude of the estimated quality medical service coefficient on the intention to recommend is 0.326 . The coefficient is positive which if the quality of medical services is increased, the higher the intention to recommend it. And conversely the lower the quality medical service, the lower the intention to recommend. Based on the value of $t$ count obtained a significance value of $0,000(p<0.05)$ so that there is a significant effect of quality medical service on the intention to recommend.

2. The magnitude of the coefficient of estimate med equipement tech on the intention to recommend is $\mathbf{0 . 4 6 0}$. The coefficient is positive which if the Med Medipement Tech increases, the higher the intention to recommend it. And conversely the lower the med equipement tech, the lower the intention to recommend. Based on the value of the calculated t obtained a significance value of $0,000(p<0.05)$ so that there is a significant effect of med equipement technology on the intention to recommend.

3. The magnitude of the estimated quality medical service coefficient on the intention to reuse is 0.411 . The coefficient is positive which if the quality of medical services is increased, the higher the intention to reuse. And conversely the lower the quality medical service, the lower the intention to reuse. Based on the value of t count obtained a significance value of $0,000(p<0.05)$ so that there is a significant effect of quality medical service on the intention to reuse.

4. The magnitude of the coefficient of estimate med equipement tech on intention to reuse is 0.113 . The coefficient is positive which if the med tech equipment is increased, the higher the intention to reuse. And conversely the lower the med equipement tech, the lower the intention to reuse. Based on the value of $t$ count 
obtained a significance value of $0.199(p<0.05)$ so that there is a significant effect med equipement technology on the intention to reuse.

\subsection{Testing of goodness of fit}

While the analysis of the inner model / structural analysis of the model is carried out to ensure that the structural models are robust and accurate. Evaluating the inner model can be seen from several indicators which include:

\subsubsection{The coefficient of determination (R2)}

Testing of the structural model is done by looking at the R-Square value which is a goodness-fit model test. Testing the inner model can be seen from the R-square value in the equation between latent variables. The $\mathrm{R} 2$ value explains how much the exogenous variable (independent / free) in the model is able to explain the endogenous variable (dependent / bound).

TABLE 5: R Square Value.

\begin{tabular}{|l|r|r|}
\hline & $\begin{array}{l}\text { R } \\
\text { Square }\end{array}$ & $\begin{array}{l}\text { R Square } \\
\text { Adjusted }\end{array}$ \\
\hline Intention to Repurchase & 0.224 & 0.220 \\
\hline Intention to Recommend & 0.453 & 0.450 \\
\hline
\end{tabular}

The value of $\mathrm{R}$ square shows the magnitude of the effect of the Quality Medical Service (X1) variable, Med Equipement Tech (X2), on the intention to recommend is 0.453 or $45.3 \%$. Then the magnitude of the effect of the Quality Medical Service (X1) and Med Equipement (X2) variables on the intention to reuse is 0.224 or $22.4 \%$.

\subsubsection{Predictive relevance $(Q 2)$}

In addition to the R-square model, it was also evaluated by looking at the $\mathrm{Q}$-square value. The value of $Q$-square can be calculated using the following calculation: $Q 2=1$ $(1-0.220)(1-0.450)=0.571$ Based on the results of the $Q$-square calculation it can be seen that the $Q$-square value is 0.571 . because the value of $Q 2>0$, it can be concluded that the research model is relevant. 


\subsubsection{Goodness of fit index (GoF)}

The last is to find the value of Goodness of Fit (GoF). Unlike CBSEM, GoF values on PLS-SEM must be searched manually. The formula is:

$$
G o F=\sqrt{\overline{A V E} \times \overline{R^{2}}} \ldots \ldots \text { Tenenhaus (2004) }
$$

The calculation result of AVE average value is 0.7088 , while the average $\mathrm{R} 2$ is 0.6075 , so the GOF value is 0.6562 According to Tenenhau (2004), the value of GoF is small $=$ 0.1 , GoF medium $=0.25$ and large $\mathrm{GoF}=0.38$.

\section{Discussion}

\subsection{Conclusion}

This study show the importance of quality service and equipment technologies to motivate patients to visit the hospital in Surabaya. Now Surabaya should aware and increasing best services for facing the medical tourism. The study indicate that the quality of medical services to have an effect on the intention to recommend health services and the intention to repurchase of health services, and patients and medical equipment technology did not have influence on the intention to recommend health services. But patients and medical equipment technology did not have influence on the intention to repurchase of health services.

\section{References}

[1] Ahmad Beltagui, Marina Candi, (2018) "Revisiting service quality through the lens of experiencecentric services", International Journal of Operations \& Production Management.

[2] Dr Vineet Jain, Puneeta Ajmera, (2018) "Modelling the factors affecting Indian Medical Tourism Sector using Interpretive Structural Modeling", Benchmarking: An International Journal.

[3] Dwi Retnaningsih, Dwi Nur Aini, Ita Yuliati, (2017) "Kepuasan Keluarga Pasien di Ruang ICU Rumah Sakit Permata Medika Semarang" Jurnal KesMaDaSka.

[4] Hafeez Idowu Agbabiaka, Emmanuel Olufemi Omisore, Oluwafemi Odunsi, (2017) "Medical tourism in Nigeria: a multivariate analysis of challenges faced By patrons", International Journal of Tourism Cities. 
[5] Jana Rosenbusch, Ida Rosnita Ismail, Christian Marc Ringle, (2018) "The agony of choice for medical tourists: a patient satisfaction index model", Journal of Hospitality and Tourism Technology.

[6] Mahendro Prasetyo Kusumo, (2017) "Pengaruh Komunikasi Terapeutik Perawat Terhadap Kepuasan Pasien di Rawat Jalan RSUD Jogja" Jurnal Medicoeticolegal dan Manajemen Rumah Sakit, 6 (1): 72-81.

[7] Shahidul Islam, (2018) "Understanding health consumer value: service marketing perspective", South Asian Journal of Business Studie.

[8] Suhana Mohezar, Sedigheh Moghavvemi, Suhaiza Zailani, (2017) "Malaysian Islamic medical tourism market: a SWOT analysis", Journal of Islamic Marketing.

[9] Sadegh Ahmadi Kashkoli, Ehsan Zarei, Abbas Daneshkohan, Soheila Khodakarim, (2017) "Hospital responsiveness and its effect on overall patient satisfaction: A crosssectional study in Iran", International Journal of Health Care Quality Assurance.

[10] Winda Arisandy, (2015) "Strategi Dinas Kesehatan dalam Meningkatkan Kualitas Pelayanan Kesehatan melalui Metode CRC (Citizen Report Card) di Kota Surabaya", Kebijakan dan Manajemen Publik, Volume 3, Nomor 2. 